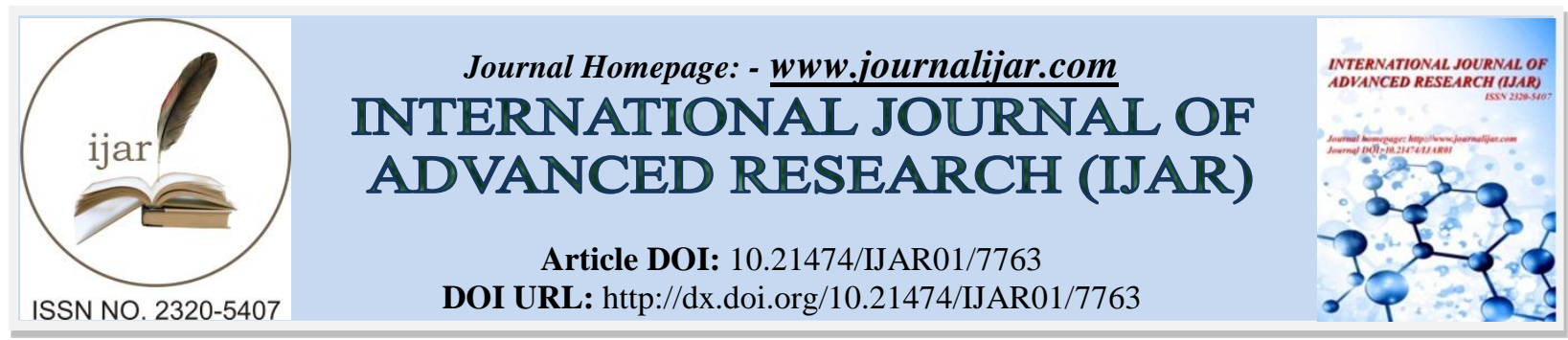

RESEARCH ARTICLE

\title{
EFFECT OF LEADERSHIP STRATEGIC, ENTREPRENEURSHIP, ORGANIZATIONAL CULTURE, AND ORGANIZATIONAL REPUTATION ON PERFORMANCE TRANSFORMER COMPANY IN INDONESIA.
}

Purnomohadi Sutedjo, Budiman Christiananta and Teman Koesmono. Universitas Katolik Widya Mandala Surabaya-Indonesia.

\section{Manuscript Info}

Manuscript History

Received: 25 July 2018

Final Accepted: 31 August 2018

Published: September 2018

Keywords:-

Strategic Leadership, Organizational

Reputation, Organizational Culture,

Entrepreneurship, Firm Performance.

\begin{abstract}
The challenges in the manufacturing industry are changing every year, the challenge is felt increasingly heavier along with the development of technology. Industry players are aware of the world of competition is getting tighter along with globalization of market and information technology. Companies are required to determine the right strategy in order to survive and win in the competition so that the goals of the company can be achieved. Good performance and sustainability is the goal every company wants to achieve. According to Resource Based Theory, the company's performance depends on its resources. The company is required to process and utilize its resources in order to improve the performance of the company.

This research has a sample of 105 middle to top level employees at Transformer company in Indonesia which consists of four factories. The data collected were analyzed by descriptive statistic and research method using SmartPLS 2.0 program.

The results of the analysis are strategic leadership, entrepreneurship, and organizational culture has a significant influence on the organizational reputation and firm performance. Another result is that strategic leadership has no significant effect on the reputation organization and the reputation organization has no significant effect on the firm performance. Of the seven hypotheses proposed there are five accepted hypotheses and two hypotheses rejected.
\end{abstract}

Copy Right, IJAR, 2018,. All rights reserved.

\section{Introduction:-}

The 35,000 Mega Watt government program opens opportunities in the electricity industry. The program causes more transmission and distribution projects, making more transformer usage. Therefore, the company is required to improve performance in order to meet market demand. Companies must implement strategies to enhance competitiveness and achieve competitive advantage.

An organization must have the ability to design and manage its business organization to be the best among its industry groups. Al-Matari et al. (2014) says that the firm's success is basically explained by its performance over a certain period of time. The above sources say that the success of a company is essentially explained from its performance results over a certain period. Firm performance is a reflection of whether the company has been successful or not in running its business. 
Research on the factors that affect the achievement of firm performance associated with the organization's internal resources (Resource Based View) becomes increasingly important as the key to organizational success to grow and develop. This is consistent with David's (2011) study, which finds that company performance is predominantly determined by internal corporate resources, such as employees, training, experience, intelligence, knowledge, skills, capabilities, information systems, patents, trademarks, copyrights , database, and others.

The results of Galbreath's (2005) research indicate that internal resources and capabilities can influence the success of an organization as stated in RBV. Internal resources and capabilities affecting company performance in this study are strategic leadership, entrepreneurship, organizational culture, and organizational reputation.

The development of strategic management studies takes place very rapidly and dramatically. The area of development is not only in practical business policy, but also in the area of empirical research. Hoskisson et al. (1999) reviews the development of strategic management studies as a pendulum showing the focus of formulation and strategy implementation, emphasizing internal or external factors. Initial development begins by linking strategies with structures that place more emphasis on internal factors (Chandler, 1962 and Ansoff, 1965). This initial development also emphasizes the suitability between strategy and structure. The pendulum then moved on to the industrial organization's contribution that placed more emphasis on external factors. Developing concepts include strategic group and structure-conduct-performance (Porter, 1980). The pendulum then moves on the contribution of transaction cost and agency theory to strategic management. Resource Base View emerges and is considered as a new perspective in strategic management. This perspective puts more emphasis on internal enterprise as a source of competitive advantage to the company (Barney, 1991).

The Resource Based Theory explains the concept of enterprise performance focusing on the company's internal resources (Grant, 1991). Barney and Hesterly (2006) say that resources are divided into two, namely tangible resources and intangible resources. Tangible resources consist of: capital, buildings, warehouses, and other facilities. Intangible resources such as: knowledge, skills, and reputation. Barney (1991) argues that a company achieves sustainable competitive advantage through its unique resources. The RBV theory states that sustainable competitive advantage rests on VRIN's organizational resources (Valuable, Rare, Inimitable, Non-substitutable in organizational settings that have policies and procedures to exploit resources (Barney, 1991, Barney \& Clark, 2007; Knott, 2003). The intangible resources further contribute to improving the company's performance.

This research was conducted at Transformer Company as one of the largest supplier of power tools used by PT. PLN Indonesia to analyze the factors that affect the improvement of industrial performance of power tools. This research was conducted in one of the transformer companies that led the domestic transformer market with a market share of 25 percent. On the financial side, transformer sales in this Company experienced an increase but profits experienced a decline. In 2017 the Company conducted an Initial Public Offering aimed at the expansion of the company.

Fortunately the current year the company has declined (Figure 1.1). The Company achieved a profit of Rp.245 billion in 2014, down 42 percent with profit of Rp.141 billion in 2015, 2.8 percent increase in 2016 with profit of Rp.145 billion. This is due to the purchase price of raw materials from suppliers and indirect production costs increased while the selling price per unit to PLN actually decreased. 


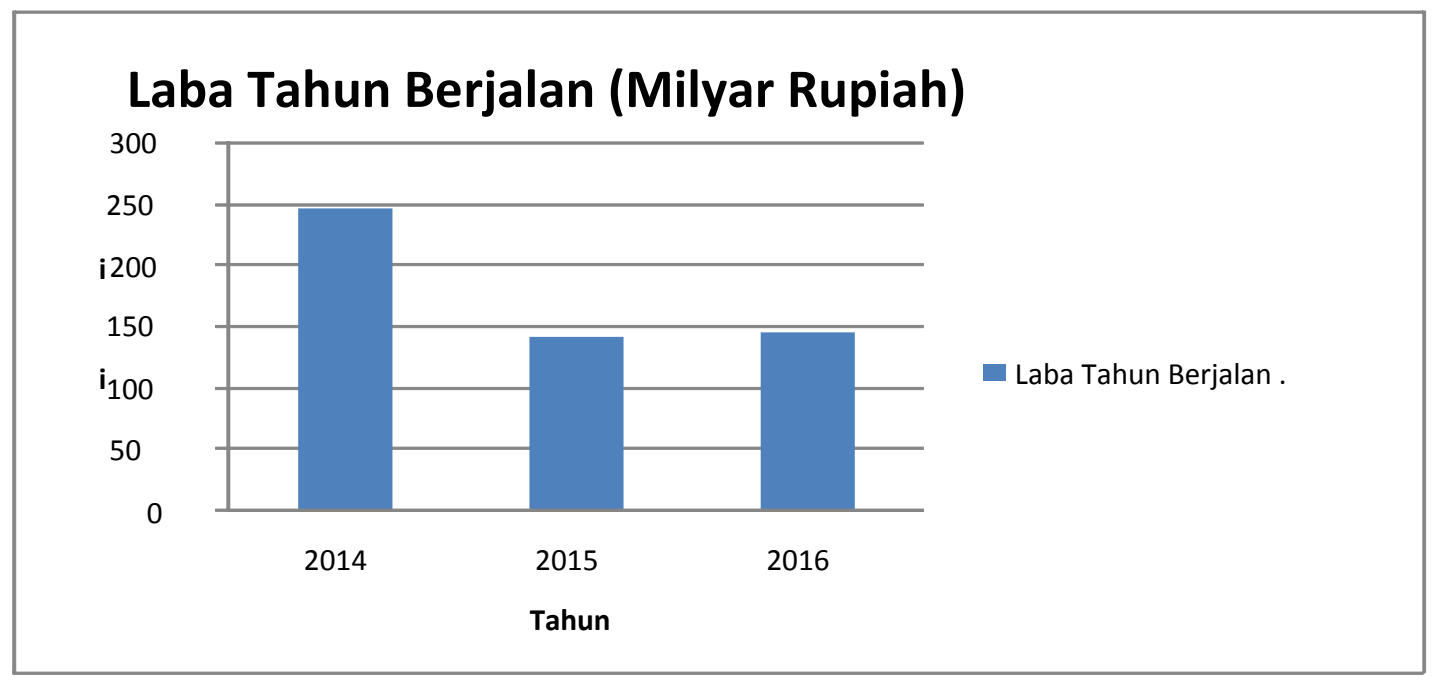

Figure 1.1:-Profit of the Current Year Source: Internal data processed

Hitt and Ireland (1999) argue that strategic leadership can be a firm competitive advantage, which can contribute to improving corporate performance. Companies with strategic leadership tend to achieve higher corporate performance and improve the company's success in its business operations (Nthini, 2013). Strategic leadership is the ability to influence the long-term viability of the organization, at the same time maintaining its short-term financial stability (Lear, 2012). Kitonga et al. (2016) conducted a study to analyze the relationship between strategic leadership and firm performance in non-profit companies in Kenya. His research is able to prove that there is a significant positive relationship between strategic leadership variables and company performance. A similar study was conducted by Ozer and Tinaztepe (2014), they examined the effect of some leadership styles relevant to strategic leadership on company performance. The results show that transformational leadership which is one of the indicators of strategic leadership has a strong effect on company performance. The results of this study differs from research conducted Brahmasari and Suprayetno (2008), Saputra (2014) which shows that leadership has no significant effect on performance.

Companies need individuals who have an entrepreneurial spirit who can provide many new ideas for the company's progress. Kuratko and Morris (2003) say the entrepreneurial organization is one in which managers are more inclined to take business-related risks, to favor innovation and change in advancing the organization's interests, and to anticipate and peremptorily respond to the actions of suppliers, competitors, customers, and other publics.

A well-grown and well-maintained organizational culture is able to lead the organization toward better development. Prajogo and McDermott (2011) conducted a study to analyze the relationship between organizational culture and performance. The results showed that organizational culture has a significant effect on company performance.

In addition to leadership, entrepreneurship, and organizational culture that affect performance, a company needs to maintain its image or reputation in the public eye because according to Resource Based View Barney's (1991) reputation theory is one of the key elements of intangible resources that will be the source of the creation of sustainable competitive advantage conditions (sustainable competitive advantage) of a company that can improve performance. Brammer et al. (2015) conducted a study to analyze the relationship between organizational reputation and firm performance with the annual survey in the UK. In his research there is a positive relationship between organizational reputation and company performance. Another study proves that there is no relationship between organizational reputation and company performance as demonstrated by research on 1500 employees 69 firms from 15 different industry sectors in Peru conducted by Feldman et al. (2014). Research gaps (differences of opinion about the results of research) of some researchers to open the study and interesting space to conduct further research to enrich the study of the factors that affect the company's performance. 


\section{Literature Review \\ Resource Based View}

Resource Based View (RBV) or Resource Based Theory (RBT) was originally introduced by Penrose in 1959 and is evolving to date as a management field study in particular on company performance. Madhani (2009) describes the development of RBV from 1959 to 1997 that internal resources and capabilities are important factors affecting sustainable competitiveness and high performance of the organization. Penrose (1959: 24) says that the company is not only an administrative unit but a collection of productive resources. The company's resources according to Barney (1991) are all assets such as: ability, organizational processes, company attributes, information, and knowledge. Enterprise resources can develop and implement strategies that improve efficiency and effectiveness.

\section{Strategic Leadership}

Global research by Weber Shandwick (2011) points out the importance of communication and executive leadership in helping to reverse the confidence of the company. A full twothirds (66\%) of consumers say that their perceptions of top leadership affect their opinions of company reputations a great deal or to a moderate degree - only seven percent say their views on the leader at the top have no bearing on corporate reputation. Empirical study of strategic leadership relates to organizational reputation (Neves and Story, 2015; Men, 2011; Men and Stacks, 2013). The results show that transformational leadership has a positive influence on the organization's reputation. Lourenco et al. (2014) argue that leadership is a signal or a sign of behavioral improvement affecting reputation, indicating that they operate according to social and ethical criteria so that firms can build a reputation. Zhu et al. (2014) argue that ethical leadership should enhance reputations that are related to CSR improvement and firm performance. Zhu et al. (2014) argue that ethical leadership should enhance reputations that are related to CSR improvement and firm performance. Some studies say that leadership affects the company's performance. As Martin et al. (2014) found that there was a positive relationship between leadership style and firm performance. His research shows that democratic leaders encourage workers' creativity and innovation, so it can be concluded that leadership contributes to effective performance within organizations. The same opinion is also said by Nthini (2013); Kitonga et al. (2016) that effective strategic leadership affects the company's performance. Companies with strategic leadership tend to achieve higher corporate performance and can improve organizational success in business operations. Then the hypothesis are:

H1: Strategic leadership has a significant effect on the organizational reputation

H4: Strategic leadership has a significant effect on firm performance.

\section{Entrepreneurship}

Lounsbury and Glynn in Hitt et al. (2001): "... develop a concept which they refer to as cultural entrepreneurship. Cultural entrepreneurship involves telling stories to enhance the entrepreneurial reputation (building legitimacy)". Orientation entrepreneurship by Zainol and Ayadurai (2011) has recently been recognized as one of the most important factors for a firm's growth and profitability. Zainol and Ayadurai (2011) studies show that entrepreneurship orientation has a direct relationship with company performance. Chen and Cangahuala (2010) examine the relationship between entrepreneurship and company performance. The results show that proactive entrepreneurship has a positive relationship with company performance. Then the hypothesis are:

$\mathrm{H} 2$ : Entrepreneurship has a significant effect on the organizational reputation.

H5: Entrepreneurship has significant effect on company performance

\section{Organizational Culture}

Organizational reputation is largely determined by the employee's attitude and work culture. Empirical studies of organizational culture and organizational reputation are carried out by Kowalczyk and Pawlish (2002); Flatt and Kowalczyk (2008). The results show that there is a consistent pattern between external cultural perceptions and reputation dimensions. Flatt and Kowalczyk (2008) in his research found that organizational culture is positively associated with the organizational reputation. Hogan and Coote (2014) argue organizational culture can help the formation process innovation and company performance. The slightly different findings are Nikpour's (2017) study that organizational culture has an indirect impact on company performance through mediation of organizational commitment. Organizational culture has a significant and positive influence on performance management practices (Ovidiu, 2014; Mujeeb, 2011; Magee, 2002; Ahmad, 2012). The results of Zakari et al. (2013), Ahmed and Shafiq (2014), and Ojo (2010) found a positive relationship between organizational culture and company performance. Then the hypothesis are:

H3: Organizational culture has a significant effect on the organizational reputation.

H6: Organizational culture has a significant effect on company performance. 


\section{Organizational Reputation}

Chun (2005) says that corporate reputation affects the way in which various stakeholders behave towards an organization, influencing, for example, employee retention, customer satisfaction and customer loyalty. Brammer et al. (2015) conducted research to analyze the relationship between organizational reputation and firm performance. In his research there is a positive relationship between organizational reputation and company performance. The results are similar to those of Ali (2014) that the organizational reputation, competition, value chain activity and resource allocation affect the firm performance. Ljubojevic and Ljubojevic (2008) argue that the organizational reputation helps the company to get good employees, attract consumers, increase consumer loyalty, which can be implemented as one of the competitive performance factors and is useful in gaining capital. Then the hypothesis are:

H7: Organizational reputation has a significant effect on the firm performance

\section{Firm Performance}

Salem (2003) defines performance as the outcomes of work because they provide the strongest linkage to the strategic goals of an organization, customer satisfaction and economic contributions. Performance by Memon and Tahir (2012) is Performance is a quality of any company or firm which can be achieved by valuable results. Wheelen and Hunger (2012: 332) define performance as a result of activity. Performance is a process of evaluation and control of strategic management. The performance of a company can be measured by various indicators, both financially and non financial.

\section{Research Issue and Methodology:- \\ Research Issue}

This research includes explanatory research or explanatory research. This is because this study aims to explain the causal relationship between variables through hypothesis testing. Explanatory research is a study that explains the relationship between research variables and hypothesis testing that has been formulated previously (Singarimbun and Effendi, 1995: 5).

\section{Methodology}

The population in this research is all employees of middle and upper level of transformer companies. The total population of 121 consists of deputy factory manager, department manager, section head, and section heads in Factories 1, Factory 2, Factory 3, and Factory 4. The population criteria as follows:

1. Deputy factory manager, department manager, section head, and head leads over a year.

2. Respondents have secondary data are data ratio, especially documents or records on the amount of labor, sales volume, production volume, and growth of the company for three years from 2014 until 2016.

3. Deputy factory manager, department manager, and head section who knows the ins and outs of the company and understands the contents of the list of statements

The sample size is determined based on Maximum Likelihood (ML) method according to the minimum requirement (Ferdinand, 2014: 173) that is the sample size of the research data suitable for SEM-PLS analysis needs is 100 to 200. This study assigns 121 respondents, for sample size has been fulfilled.

Table 3.1:-Population at Transformer Company

\begin{tabular}{|l|l|l|l|l|l|l|}
\hline No/Kluster & Pabrik & $\begin{array}{l}\text { Deputy Factory } \\
\text { Manager }\end{array}$ & $\begin{array}{l}\text { Manager } \\
\text { Departemen }\end{array}$ & $\begin{array}{l}\text { Kepala } \\
\text { Bagian }\end{array}$ & $\begin{array}{l}\text { Kepala } \\
\text { Seksi }\end{array}$ & Populasi \\
\hline 1 & Pabrik 1 & 1 & 7 & 9 & 13 & 30 \\
\hline 2 & Pabrik 2 & 1 & 7 & 9 & 15 & 32 \\
\hline 3 & Pabrik 3 & 1 & 7 & 8 & 12 & 28 \\
\hline 4 & Pabrik 4 & 1 & 7 & 8 & 15 & 31 \\
\hline & TOTAL & & & & & 121 \\
\hline
\end{tabular}

Source: Results of questionnaire data collection processed.

Respondents in Table 3.1 consisted of 121 middle and upper level employee population of Transformer Company from the total population of 121 people consisting of 4 factories, namely: Factory 1 of 30 people, Factory 2 of 32 people, Factory 3 of 28 people, and Factory 4 of 31 people. Of the population, the sample used in this study amounted to 105 pieces based on the number of returned questionnaires. 
Findings and Discussion:-

Findings

Descriptive Statistic

Characteristics of Responden by Gender

Descriptions of respondents according to gender based on questionnaires are shown in Table 4.1 as follows:

Table 4.1:-Descriptive Data of Gender Respondent

\begin{tabular}{|l|l|l|}
\hline Gender & Amount & Percentage \\
\hline Man & 87 & $83 \%$ \\
\hline Woman & 18 & $17 \%$ \\
\hline Total & 105 & $100 \%$ \\
\hline
\end{tabular}

\section{Source: Results of questionnaire data collection processed.}

Table 4.1 shows the characteristics of respondents based on gender classification that is about 87 people (83 percent) are male and about 18 people (17 percent) are women. High-level employee at Transformer company is mostly male.

\section{Characteristics of Responden by Age}

Descriptions of respondents according to age based on questionnaires are shown in Table 4.2 as follows:

Table 4.2:-Descriptive Data of Age Respondent

\begin{tabular}{|c|l|l|}
\hline Age & Amount & Percentage \\
\hline $26-35$ & 29 & $28 \%$ \\
\hline $36-45$ & 63 & $60 \%$ \\
\hline $46-55$ & 12 & $11 \%$ \\
\hline$>55$ & 1 & $1 \%$ \\
\hline Total & 105 & $100 \%$ \\
\hline
\end{tabular}

Source: Results of questionnaire data collection processed.

The results of distributing questionnaires received information that employees aged between 26-35 years were 29 respondents (28 percent), 36-45 years as many as 63 respondents (60 percent), 46-55 years as many as 12 respondents (11 percent), and >55 years as many as 1 respondent ( 1 percent). The age classification of most respondents was in the category between $36-45$ years.

\section{Characteristics of Respondents by The Last Education:-}

Descriptions of respondents according to the last education based on questionnaires are shown in Table 4.3 as follows:

Table 4.3:-Descriptive Data of The Last Education

\begin{tabular}{|c|l|l|}
\hline Last Education & Amount & Percentage \\
\hline SMU & 18 & $17 \%$ \\
\hline D3 & 14 & $13 \%$ \\
\hline S1 & 64 & $61 \%$ \\
\hline Total & 9 & $9 \%$ \\
\hline
\end{tabular}

Source: Results of questionnaire data collection processed.

Table 4.3 shows the last education of middle and upper level employees of transformer company namely: 18 respondents (18\%) educated to high school, 14 respondents (13\%) educated up to D3, 64 respondents $(61 \%)$ educated up to S1, and 9 respondents (9\%) educated up to S2.

Characteristics of Respondents by Length of Work

Descriptions of respondents according to the last education based on questionnaires are shown in Table 4.4 as follows: 
Table 4.4:-Descriptive Data of Length of Work

\begin{tabular}{|c|l|l|}
\hline Length of Work (Year) & Amount & Percentage \\
\hline$<3$ & 13 & $12 \%$ \\
\hline$>3-4$ & 42 & $40 \%$ \\
\hline$>4$ & 50 & $48 \%$ \\
\hline Total & 105 & $100 \%$ \\
\hline
\end{tabular}

Source: Results of questionnaire data collection processed.

Table 4.4 shows 13 respondents (12 percent) have worked for 2-3 years, 42 respondents (40 percent) have worked for 3-4 years, and 50 respondents (48 percent) have worked for more than 4 years. Based on this description it appears that the majority of respondents have worked at Transformer company for more than 4 years.

\section{Outer Model}

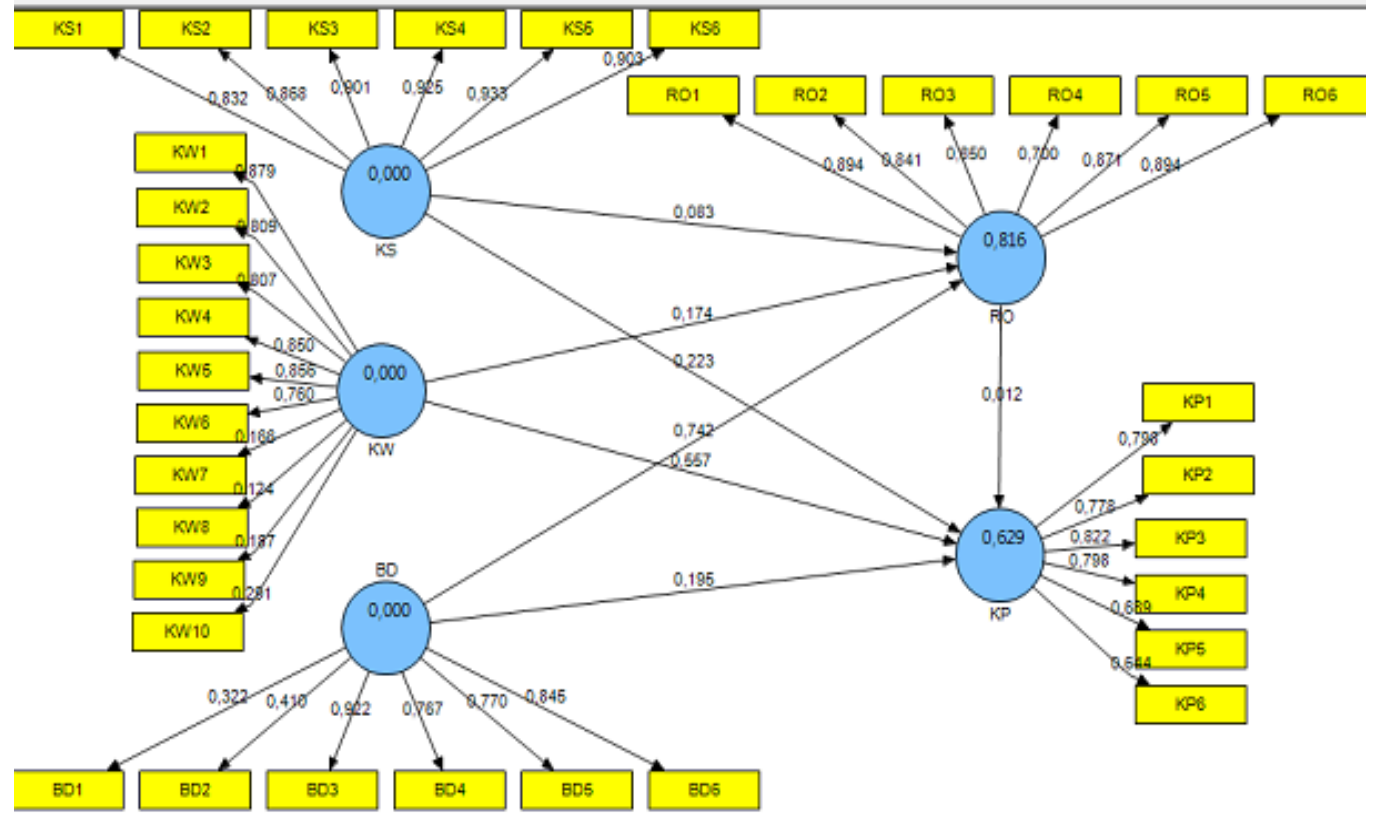

Figure 4.1:-SEM Model Early Results

Source: SmartPls 2.0, processed

The results of the complete model testing above with the SmartPLS program can be seen from the R-Square value which describes the goodness-of-fit of a model. The recommended R-square value is greater than zero. The results of this research data processing by using SmartPLS give the R-square value as shown in Table 4.6.

\section{Average Variance Extracted (AVE)}

Another method for assessing discriminat validity is comparing the value of the square root of average variance extracted (AVE) of each construct with the correlation between constructs and other constructs in the model. AVE value is declared satisfactory if $>0.5$, the results of the AVE test appear in the following Table 4.5.

Table 4.5:-AVE Result

\begin{tabular}{|l|l|}
\hline Variabel & AVE Result \\
\hline Strategic Leadership (X1) & 0,799791 \\
\hline Entrepreneurship (X2) & 0,427504 \\
\hline Organizational Culture (X3) & 0,503164 \\
\hline Organizational Reputation (Y1) & 0,712697 \\
\hline Firm Performance (Y2) & 0,573635 \\
\hline
\end{tabular}

Source: SmartPls 2.0, processed 
R-Square values that illustrate the goodness-of-fit of a model. The recommended R-square value is greater than zero. The results of this research data processing by using SmartPLS give the R-square value as shown in Table 4.6.

Table 4.6:-R-Square

\begin{tabular}{|l|l|}
\hline Variable & R-Square \\
\hline $\begin{array}{l}\text { Strategic Leadership (X1), Entrepreneurship (X2), Organizational Culture (X3) > } \\
\text { Organizational Reputation (Y1) }\end{array}$ & 0,816068 \\
\hline $\begin{array}{l}\text { Strategic Leadership (X1), Entrepreneurship (X2), Organizational Culture (X3) > Firm } \\
\text { Performance (Y2) }\end{array}$ & 0,628625 \\
\hline
\end{tabular}

Source: SmartPls 2.0, processed

Table 4.6 explains that the contribution or proportion of the variables of Strategic Leadership, Entrepreneurship (X2), Organizational Culture (X3) on Organizational Reputation (Y1) of 0.816, Strategic Leadership variables, Entrepreneurship (X2), Organizational Culture (X3) on company performance (Y2) as broad as 0.628 . The result of all R-Square values shows that all R-Square values are greater than zero. This means that this research model has fulfilled the required Goodness of Fit.

\section{Hypothesis Test Results:-}

The results of the coefficient of structural paths (inner weight) along with the significance values are shown in Table 4.7.

Table 4.7:-Inner Weight Test On Company Performance With Bootstrap Samples

\begin{tabular}{|l|l|l|l|l|l|l|l|}
\hline Effect & \multirow{2}{*}{$\begin{array}{l}\text { Original } \\
\text { coeff }\end{array}$} & \multicolumn{2}{l|}{ (Bootstrap, B=100) } & \multicolumn{2}{l|}{ (Bootstrap, B=300) } & \multicolumn{2}{l|}{ (Bootstrap, B=500) } \\
\cline { 3 - 7 } & Coeff. & Uji t & Coeff. & Uji t & Coeff. & Uji t \\
\hline $\begin{array}{l}\text { Strategic Leadership (X1) -> } \\
\text { Organizational Reputation } \\
\text { (Y1) }\end{array}$ & 0.083 & 0.083 & 1.356 & 0.083 & 1.290 & 0.088 & 1.349 \\
\hline $\begin{array}{l}\text { Entrepreneurship (X2) - } \\
\text { > Organizational Reputation } \\
\text { (Y1) }\end{array}$ & 0.174 & 0.165 & 2.978 & 0.173 & 2.933 & 0.171 & 2.660 \\
\hline $\begin{array}{l}\text { Organizational Culture (X3) - } \\
\text { > Organizational Reputation } \\
\text { (Y1) }\end{array}$ & 0.742 & 0.748 & 9.811 & 0.741 & 10.217 & 0.737 & 9.899 \\
\hline $\begin{array}{l}\text { Strategic Leadership (X1) -> } \\
\text { Firm Performance (Y2) }\end{array}$ & 0.223 & 0.223 & 2.044 & 0.227 & 2.275 & 0.219 & 2.225 \\
\hline $\begin{array}{l}\text { Entrepreneurship (X2) -> } \\
\text { Firm Performance (Y2) }\end{array}$ & 0.557 & 0.558 & 4.977 & 0.555 & 5.721 & 0.567 & 5.248 \\
\hline $\begin{array}{l}\text { Organizational Culture (X3) - } \\
>\text { Firm Performance (Y2) }\end{array}$ & 0.195 & 0.199 & 1.937 & 0.200 & 1.906 & 0.192 & 1.857 \\
\hline $\begin{array}{l}\text { Organizational Reputation } \\
\text { (Y1) -> Firm Performance } \\
\text { (Y2) }\end{array}$ & 0.012 & -0.002 & 0.071 & -0.008 & 0.081 & 0.008 & 0.077 \\
\hline
\end{tabular}

Source: SmartPls 2.0, processed

\section{Discussion;-}

The results of hypothesis testing based on the results of the PLS analysis show that the hypothesis about strategic leadership has no significant influence on the reputation of the organization. This can mean that changes in strategic leadership do not bring changes to the organization's reputation positively.

The results of hypothesis testing based on the results of the PLS analysis show that the hypothesis about entrepreneurship has a significant direct influence on the reputation of the organization can be accepted. This can mean that changes in the entrepreneurial process will positively change the reputation of the organization. The better the entrepreneurship of an organization, the better the reputation of the organization. The results of this study reinforce the opinion of Chousa et al. (2016) which says entrepreneurship views reputation as a competitive advantage so it must actively manage relationships with stakeholders and find innovative opportunities. The results 
of this study also reinforce the opinion of Miles et al. (2009) that managers who embrace entrepreneurship can produce discovery or creation and assessment so as to enhance the company's reputation and competitive advantage.

The results of the PLS analysis of this study prove that there is a direct influence of organizational culture variables on the organizational reputation. The results of this study are in line with the findings of Kowalczyk and Pawlish (2002). The results of this study also strengthen the research of Flatt and Kowalczyk (2008) which proves that organizational culture is positively related to the reputation of the organization.

The results of the PLS analysis of this study prove that there is a direct influence on the variables of strategic leadership on company performance. The results of this study strengthen the research conducted by Avery (2008) that effective leadership behavior influences company performance. Leadership can encourage employees to work better, which ultimately contributes to improving company performance.

The results of PLS analysis of this study prove that there is a direct influence of entrepreneurship variables on company performance. The results of this study support the findings of previous studies, among others: Zainol and Ayadurai (2011) research that puts entrepreneurship as one of the most important factors for sales growth and corporate profitability which is an element of corporate performance. Chen and Cangahuala's research (2010) prove that entrepreneurship has a positive relationship with company performance. The results of this study are also supported by research conducted by Antoncic and Scarlat (2005) which also found the influence of entrepreneurship on company performance.

The results of PLS analysis of this study prove that there is a direct influence of organizational culture variables on company performance. The results of this study reinforce the research of Mujeeb et al. (2011), which suggests that organizational culture is an important aspect of a company, because it can affect employee behavior which ultimately affects the company's performance. The results of this study also reinforce Ovidiu's (2014) research findings that a strong culture helps organizations anticipate and adapt to environmental changes. A strong culture is a culture where employees work together effectively, share and take decisions together to meet company goals. The results of his research prove that organizational culture has a positive impact on company performance.

The results of hypothesis testing based on the results of the PLS analysis show that the hypothesis about the reputation of the organization has a significant direct influence on the performance of the company cannot be accepted. This is because individuals in the company see that the organization's reputation is only limited to the image of the company, not a resource that can create competitive advantage. Organizational reputation has not gone well in the company, indicated by the absence of good waste management and community economic assistance programs. In addition, the company has not been able to respond to customer demands beyond its competitors. In terms of price, it still cannot compete with competitors, but has a high quality product. The results of this test support the findings of Inglis et al. (2006) who found that there was no relationship between organizational reputation and company performance. This is also in line with the results of Blajer's (2014) study which states that organizational reputation and economic performance have weak relationships. Companies that have good performance and have more funds, will be more aware of the importance of participating in CSR programs (one form of organizational reputation).

\section{Conclusion, Limitation and Research Extention:- Conclusion:-}

The results of the PLS analysis of this study prove that there is no direct relationship between leadership strategic and organizational reputation. The results of the research hypothesis show that the positive-signed coefficient is 0.083 with t-statistics of 1.349 smaller than $t$ table 1.659 . This is what drives the variables of strategic leadership in organizational reputation to be insignificant. It can be concluded that the variables of strategic leadership do not have a significant effect on the positive direction of the variables not in accordance with the proposed hypothesis.

The results of the PLS analysis of this study prove that there is a direct influence of entrepreneurship variables on organizational reputation. The results of the analysis in Table 4.22 can be seen that the results of hypothesis testing shows a positive coefficient path of 0.174 with a t-statistic of 2.660 greater than $t$ table 1.659 . This illustrates that the influence of entrepreneurship variables on organizational reputation is significant. It can be concluded that 
entrepreneurial variables have a significant effect on the positive direction of the organization's reputation variables in accordance with the proposed hypothesis.

The PLS analysis results of this study prove that there is a direct influence of organizational culture variables on organizational reputation. Hypothesis test results show a positive path coefficient of 0.742 with a t-statistic of 9.899 greater than $\mathrm{t}$ table 1.659. This illustrates that the influence of organizational culture variables on organizational reputation is significant. It can be concluded that organizational culture variables have a significant effect on the positive direction of organizational reputation variables in accordance with the proposed hypothesis.

The PLS analysis results of this study prove that there is a direct influence of entrepreneurship variables on company performance. Hypothesis test results show a positive path coefficient of 0.557 with a t-statistic of 5.248 greater than $t$ table 1.659. This illustrates that the influence of entrepreneurship variables on company performance is significant. It can be concluded that entrepreneurship variables have a significant effect on the positive direction of the company's performance variables in accordance with the proposed hypothesis.

The results of PLS analysis of this study prove that there is a direct influence of organizational culture variables on company performance. Hypothesis test results indicate a positive path coefficient of 0.195 with a t-statistic of 1.857 greater than $\mathrm{t}$ table 1.659. This illustrates that the influence of organizational culture variables on company performance is significant. It can be concluded that organizational culture variables have a significant effect on the positive direction of the company's performance variables in accordance with the proposed hypothesis.

The results of the PLS analysis of this study prove that there is no direct influence on organizational reputation variables on company performance. Hypothesis test results show a positive path coefficient of 0.012 with a t-statistic of 0.077 smaller than $t$ table 1.659. This illustrates that the influence of organizational reputation variables on company performance is insignificant. It can be concluded that the organization's reputation has no significant effect on the company's performance variables not in accordance with the proposed hypothesis.

\section{References:-}

1. Ahmad, M.S. 2012. Impact of Organizational Culture on Performance Management Practices in Pakistan. Business Intelligence Journal, Vol.5, No.1, pp. 50-55.

2. Ahmed, M. dan Saima. S. 2014. The Impact of Organizational Culture on Organizational Performance:A Case Study on Telecom Sector. Global Journal Of Management And Business Research. Retrieved 04 Juli 2017 from https://www.journalofbusiness.org/index.php/GJMBR/article/view/1254

3. Ali, I.M. 2014. Corporate Brand Equity and Firm Performance in The Pharmaceutical Industry in Kenya. Master of Science Project. University of Nairobi.

4. Ansoff, Igor. 1965. Corporate Strategy. New York: McGraw Hill.

5. Antoncic, B. dan Scarlat, C. 2008. Corporate Entrepreneurship Performance: Slovenia and Romania. Management, Vol. 3 (1), 15-38.

6. Barney, J. 1991. Firm Resources and Sustained Competitive Advantage. Journal of Management, Vol. 17(1), pp. 99-120.

7. ---., dan Hesterly, W.S. 2006. Strategic Management and Competitive Advantage: Concepts and Cases. London: Pearson Education.

8. Brahmasari dan Suprayetno. 2008. Pengaruh Motivasi Kerja, Kepemimpinan dan Budaya Organisasi Terhadap Kepuasan Kerja Karyawan serta Dampaknya Pada Kinerja Perusahaan (Studi Kasus Pada PT Pei Hai Internasional Wiratama Indonesia). Jurnal Manajemen dan Kewirausahaan, Vol.10, No. 2, hal. 124-135.

9. Brammer, S., Agarwal, V., Taffler, R., dan Brown, M. 2015. Corporate Reputation and Financial Performance: The Interaction between Capability and Character. In European Financial Management Association. 2015 Annual Meeting: The Netherlands.

10. Chandler, Alfred. 1965. Strategy and Structure: Chapters in The History of Industrial Enterprise. New York: Doubleday.

11. Chen, M. H. dan Cangahuala, G. 2010. Corporate Entrepreneurship Environment and Organizational Performance in Technology Manufacturing Sector. Technology Management for Global Economic Growth (PICMET). Proceedings of PICMET'10, IEEE, pp. 1-9.

12. Chun, R. 2005. Corporate Reputation: Meaning and Measurement. International Journal of Management Reviews, Vol. 7(2), pp. 91-109. 
13. Covin, J.G. dan Miles, M.P. 1999. Corporate Entrepreneurship and the Pursuit of Competitive Advantage. Entrepreneurship, Theory. and Practice, Vol. 23 (3), pp. 47-63.

14. David, F. R. 2011. Strategic Management Concepts and Cases. London: Pearson Education.

15. Feldman, P. M., Bahamonde, R. A. dan Velasquez Bellido, I. 2014. A New Approach for Measuring Corporate Reputation. Revista de Administração de Empresas, Vol. 54(1), 53-66.

16. Ferdinand, A. 2005. Metode Penelitian Manajemen: Pedoman Penelitian untuk Penulisan Skripsi Tesis dan Disertasi Ilmu Manajemen. Semarang: Badan Penerbit Universitas Diponegoro.

17. ---. 2014. Metode Penelitian Manajemen: Pedoman Penelitian untuk Penulisan Skripsi Tesis dan Disertasi Ilmu Manajemen. Semarang: Badan Penerbit Universitas Diponegoro

18. Flatt, S.J dan Kowalczyk, S.J. 2008. Creating Competitive Advantage Through Intangible Assets: The Direct and Indirect Effects of Corporate Culture and Reputation. Advances in Competitiveness Research, Vol. 16 (1\&2), 13.

19. Grant, R. M. 1991. The Resource-Based Theory of Competitive Advantage: Implications for Strategy Formation. California Management Review, Vol. 33, No. 3, pp. 114.

20. Hitt, M.A. dan Ireland, R.D. 1999. Achieving and Maintaining Strategic Competitiveness in the 21st Century: The Role of Strategic Leadership. The Academy of Management Executive, Vol. 13(1), 43-57.

21. ---., Camp, S.M., dan Sexton, D.L. 2001. Guest Editors' Introduction To The Special Issue Strategic Entrepreneurship: Entrepreneurial Strategies For Wealth Creation. Strategic Management Journal, Vol. 22, pp. 479-491.

22. Hogan, S.J. dan Coote, L.V. 2014. Organizational Culture, Innovation, and Performance: A Test of Schein's Model. Journal of Business Research, Vol. 67(8), 1609-1621.

23. Hoskisson, R.E., Hitt, M.A., Wan, W.P., dan Yiu, D. 1999. Theory and Research in Strategic Management: Swings of A Pendulum. Journal of Management, Vol. 25, No. 3, pp. 417-456.

24. Inglis, R., Morley, C., dan Sammut, P. 2006. Corporate Reputation and Organisational Performance: An Australian Study. Managerial Auditing Journal, Vol.21, No.9, pp. 934-947.

25. Kitonga, D. M., Bichanga, W. O. dan Muema, B. K. 2016. Strategic Leadership And Organizational Performance In Not-For-Profit Organizations In Nairobi County In Kenya. International Journal of Scientific \& Technology Research, Volume 5, Issue 05.

26. Kowalczyk, S. J. dan Pawlish, M. J. 2002. Corporate Branding Through External Perception of Organizational Culture. Corporate Reputation Review, Vol. 5(2-1), pp. 159-174.

27. Kuratko, D. F dan Morris, M. H. 2003. Corporate Entrepreneurship: The Dynamic Strategy for 21st Century Organizations. Issues in Entrepreneurship, pp. 21-46.

28. Lear, L. W. 2012. The relationship between strategic leadership and strategic alignment in high-performing companies in South Africa. Doctoral Dissertation. University of South Africa.

29. Ljubojevic, C dan Ljubojevic, G. 2008. Building Corporate Reputation through Corporate Governance. Management. Vol. 3 Issue 3, pp. 221-233.

30. Lourenco, I. C., Callen, J. L., Branco, M. C. dan Curto, J. D. 2014. The Value Relevance of Reputation for Sustainability Leadership. Journal of Business Ethics, Vol. 119(1), pp. 17-28.

31. Madhani, Pankaj. 2009. Resource Based View (RBV) of Competitive Advantage: An Overview. Hyderabad: Icfai University Press.

32. Magee, K.C. 2002. The impact of organizational culture of implementation of performance management. Dissertation. 